\title{
Evaluation of some physical fitness characteristics at age 11 to 13
}

\author{
Ileana-Monica POPOVICI'1, Lucian POPESCU², Liliana-Elisabeta RADU³
}

\begin{abstract}
Many studies indicate that an adequate physical fitness is an important marker for a healthy body and a healthy mind. The aim of the study was investigate the level of physical fitness of students aged 11-13. Depending on the results, we will determine the type of measures to propose in order to improve the obtained data.

251 volunteer students participated in this research, including 95 boys and 156 girls aged 11 to 13, who participated in the physical education class two times a week. Subjects underwent six anthropometric characteristics and five physical tests. For the statistical analysis the mean, standard deviation, and multiple comparisons were used in order to find the differences between genders, using Anova and Bonferoni Test for differences between certain age groups. Anthropometric measurements included height, weight, arm span, waist, hip, body mass index and physical testing as agility, balance and strength.

The findings suggest some differences between male and female subjects, as well as between age groups, namely boys obtained higher mean results compared to girls.
\end{abstract}

Key words: Anthropometrics, agility, balance, strength, students

\section{Rezumat}

Studiile științifice relevă faptul că o condiție fizică bună este un factor important pentru un corp sănătos și o minte sănătoasă. Scopul acestui studiu este de a investiga nivelul de aptitudini fizice la elevi de 11-13 ani. În conformitate cu rezultatele înregistrate, vom stabili ce fel de măsuri pot fi propuse pentru a îmbunătăți bagajul motric și implicit calitățile motrice.

În această cercetare au participat, în mod voluntar, 251 de elevi, dintre care 95 de băieți și 156 fete, cu vârsta cuprinsă între 11-13 și care au participat la lecția de educație fizică de două ori pe săptămână. Au fost realizate șase măsurători antropometrice și cinci teste fizice. Pentru analiza statistică am utilizat media, deviația standard și comparația multiplă, pentru a afla diferențele între genuri, cu ajutorul Anova și Bonferoni pentru diferențele între vârste. Măsurătorile antropometrice au fost raportate ca: înălțime, greutate, anvergura, perimetrul abdomenului, perimetrul șoldului și indicele de masa corporala, iar pentru testările fizice ca agilitate, echilibrul si forță.

Constatările sugerează unele diferențe intre fete și băieți , precum și pe categorii de vârstă, iar băieții au obținut rezultate mai bune în comparație cu fetele.

Cuvinte cheie: Antropometrie, agilitate, echilibru, forță, elevi

\footnotetext{
${ }^{1}$ Lecturer PhD, Alexandru Ioan Cuza University of Iași, Faculty of Physical Education and Sport

${ }^{2}$ Associate professor, PhD, Alexandru Ioan Cuza University of Iași, Faculty of Physical Education and Sport

${ }^{3}$ Associate professor, PhD, Alexandru Ioan Cuza University of Iași, Faculty of Physical Education and Sport, e-mail: liliana.radu@uaic.ro
} 


\section{Introduction}

Regular physical activity plays a significant role in enhancing and maintaining human health [1], and is generally considered to be necessary for adequate growth and development [2]. At the same time, physical activity in children is a preventive and therapeutic measure to reduce the risk of future diseases such as obesity and cardiovascular diseases $[3,4]$.

Physical education in terms of an educational process consists of helping children and adolescents acquire skills, fitness, knowledge, and attitudes that contribute to their optimal development and wellbeing. Some physical fitness characteristics are taken into consideration for our paper: agility, balance and upper limb strength, lower limb and abdominal muscles. For many, balance is a complex part of the individual motor fitness and it is influenced by vision and the ability to maintain one's equilibrium in relation to the gravitational force and to make rapid body alternations when it is placed in various positions [5].

Balance is a mechanical condition, indispensable for the motor function, as it ensures the stability of positions (posture) and the orientation of movements in space; hence, it is required both in daily and professional, as well as in sports activities [6]. Agility is the ability to quickly change position or direction of the body and is also influenced by body balance, coordination, the position of the centre of gravity, as well as running speed and skill [7]. Power represents the ability to perform one maximum effort in as short time as possible, also known as explosive power. The combination of strength and speed is exhibited during jumping, striking, or distance throwing [5].

\section{Methods and subjects}

The study was carried out on 252 students within the "Mihai Eminescu" National College of Iasi, Romania (158 girls and 94 boys) aged between 11 and 13. We mention that for our research the purpose of the study was explained to all participants and the written consent from parents and students was obtained.

The anthropometric measurements included five evaluation criteria for the physical status: weight, height, arm span, waist and hip. Based on the first two measurements, we calculated the Body Mass Index (BMI).

Each subject was measured in accordance with the standard methods proposed by the International Society for the Advancement of Kinanthropometry [8] for:

- Basic measurements (height, weight). Equipment used included a stadiometer and a weighing scale. Height characteristics were measured to the nearest $0.1 \mathrm{~cm}$, and mass characteristic was measured in $\mathrm{kg}$.

- Girths (waist and hip circumference). Both were measured with anthropometric tape and expressed in $\mathrm{cm}$.

- Arm span was measured from one medium fingertip to another, while standing with the back to a flat wall and arms stretched with palms facing the investigator. The equipment required consisted of a tape measure on the wall, marked in $\mathrm{cm}$.

- The body mass index (BMI) was calculated according to the formula weight $(\mathrm{kg}) /$ total height ${ }^{2}\left(\mathrm{~m}^{2}\right)$, and it indicates the ratio between the weight and height of a person.

The subjects performed three physical fitness tests in order to assess agility, balance and strength of abdominal, lower limb and lower limb muscles [7].

- Standing Long Jump (SLJ) was used to assess explosive power and strength. The test performed from static position behind a line and jumping as far as possible by swinging arms foreword. Subjects performed two jumps and the best result $(\mathrm{cm})$ was recorded.

- Sit Ups Test. From lying on the floor with knees bent, feet flat on the floor and arms folded across the chest, subjects were asked to rise to the $90^{\circ}$ degree position and return to the floor. The number of executions in 30 seconds was registered.

- 10x5m shuttle test. The subject runs to the opposite marker at 5-m distance from starting line, turns and returns to the starting line. This is repeated five times without stopping (covering $50 \mathrm{~m}$ in total). The total time in seconds is recorded.

- Flamingo Test. The subjects completed the test on the dominant foot; the test included a wood beam stabilized by two supports at each end. From standing on one leg on the beam with shoes removed, the free leg is flexed at the knee and the foot of this leg held close to the buttocks. The number of falls in 60 seconds of balancing is counted. In case of more than 15 falls in the first 30 seconds, the test is finished and score is zero.

- Overhead Medicine Ball Throw. The ball is brought back behind the head, and then thrown vigorously forward as far as possible. The subject is permitted to step forward over the line after the ball is released, and is in fact encouraged to do so, thus maximizing the distance of the throw. Three attempts are allowed and the best result is recorded.

For data evaluation, descriptive statistics including the mean $(X)$ and standard deviation (SD) were calculated. Differences of means were analysed with 
Anova and multiple comparisons with Bonferoni using the SPSS version 17.0 for Windows. The differences were considered significant if $p$ value was less than 0.05 .

\section{Results}

Anthropometric characteristics of the male participants are presented in Table I. Groups were divided by ages of subjects (group $1=11$ years old; group 2 = 12 years old; group $3=13$ years old).

We observed that results are similar between the first two groups for all measurement and higher scores were recorded for the group of the 13 yearolds.

Table I. Anthropometric measurements by age (boys)

\begin{tabular}{|c|c|c|c|c|c|c|}
\hline & Weight & Height & $\begin{array}{l}\text { Arm } \\
\text { span }\end{array}$ & BMI & Waist & Hip \\
\hline $\begin{array}{l}\text { Gr. } 1 \\
(\mathrm{~N}=9)\end{array}$ & $\begin{array}{l}39.00 \\
\pm 11.21 \\
\end{array}$ & $\begin{array}{l}1.46 \\
\pm 0.08 \\
\end{array}$ & $\begin{array}{l}146.33 \\
\pm 7.50 \\
\end{array}$ & $\begin{array}{l}1.33 \\
\pm 0.50 \\
\end{array}$ & $\begin{array}{r}71.22 \\
\pm 8.85 \\
\end{array}$ & $\begin{array}{r}80.55 \\
\pm 8.00 \\
\end{array}$ \\
\hline $\begin{array}{l}\text { Gr. } 2 \\
(\mathrm{~N}=43)\end{array}$ & $\begin{array}{l}41.48 \\
\pm 9.80 \\
\end{array}$ & $\begin{array}{l}1.49 \\
\pm 0.08\end{array}$ & $\begin{array}{l}148.93 \\
\pm 7.51 \\
\end{array}$ & $\begin{array}{l}1.46 \\
\pm 0.54\end{array}$ & $\begin{array}{r}71.53 \\
\pm 5.54\end{array}$ & $\begin{array}{r}80.07 \\
\pm 5.42 \\
\end{array}$ \\
\hline $\begin{array}{l}\text { Gr. } 3 \\
(\mathrm{~N}=42)\end{array}$ & $\begin{array}{l}49.44 \\
\pm 10.91 \\
\end{array}$ & $\begin{array}{l}1.58 \\
\pm 0.08 \\
\end{array}$ & $\begin{array}{l}159.71 \\
\pm 9.29 \\
\end{array}$ & $\begin{array}{l}1.74 \\
\pm 0.58 \\
\end{array}$ & $\begin{array}{l}76.41 \\
\pm 7.20 \\
\end{array}$ & $\begin{array}{r}83.02 \\
\pm 7.54 \\
\end{array}$ \\
\hline $\begin{array}{l}\text { Total } \\
(\mathrm{N}=94)\end{array}$ & $\begin{array}{l}44.80 \\
\pm 11.17 \\
\end{array}$ & $\begin{array}{l}1.52 \\
\pm 0.09 \\
\end{array}$ & $\begin{array}{l}153.50 \\
\pm 10.02 \\
\end{array}$ & $\begin{array}{l}1.57 \\
\pm 0.57 \\
\end{array}$ & $\begin{array}{r}73.68 \\
\pm 7.04 \\
\end{array}$ & $\begin{array}{r}81.43 \\
\pm 6.78 \\
\end{array}$ \\
\hline
\end{tabular}

Characteristics of girls are presented in Table II. Similar results were found between the first two groups and the third.

Table II. Anthropometric measurements by age (girls)

\begin{tabular}{lllllll}
\hline & Weigh & Heigh & Arm & BMI & Wais & Hip \\
& $\mathrm{t}$ & $\mathrm{t}$ & span & & $\mathrm{t}$ & \\
\hline Gr. 1 & 42.26 & 1.47 & 146.0 & 1.66 & 72.73 & 82.80 \\
$(\mathrm{~N}=15)$ & \pm 4.59 & \pm 7.71 & 0 & \pm 0.7 & \pm 10.2 & \pm 10.3 \\
& & & \pm 10.6 & 2 & 8 & 3 \\
& & & 5 & & & \\
\hline Gr. 2 & 42.42 & 1.50 & 149.6 & 1.47 & 73.09 & 82.25 \\
$(\mathrm{~N}=89)$ & \pm 11.03 & \pm 0.07 & $2 \pm 7.3$ & \pm 0.6 & \pm 8.98 & \pm 10.5 \\
& & & 7 & 4 & & 3 \\
\hline Gr. 3 & 50.63 & 1.57 & 1.56 & 1.74 & 76.68 & 85.57 \\
(N=54) & \pm 10.92 & \pm 0.06 & \pm 6.70 & \pm 0.6 & \pm 7.44 & \pm 8.58 \\
& & & & 7 & & \\
\hline Total & 45.21 & 1.51 & 151.7 & 1.62 & 74.28 & 83.44 \\
(N=158 & \pm 11.95 & \pm 2.37 & 7 & \pm 0.6 & \pm 8.74 & \pm 9.95 \\
) & & & \pm 8.33 & 6 & & \\
\hline
\end{tabular}

In Table III we presented the results of physical fitness measurements and observed that in all tests, group 2 (12 years old) obtained the lower performance. Among the girls group (Table IV) we observed that the lower performances were obtained by the first group in standing long jump, balance and medicine ball throw, second group for 10x5 $\mathrm{m}$ shuttle run and group 3 in sit-up.

Table III. Physical fitness measurements by age (boys)

\begin{tabular}{|c|c|c|c|c|c|}
\hline & SLJ & Sit-up & $10 \times 5 \mathrm{~m}$ & Flamingo & Ball throw \\
\hline $\begin{array}{l}\text { Gr. } 1 \\
(\mathrm{~N}=9)\end{array}$ & $\begin{array}{l}1.49 \\
\pm 0.17\end{array}$ & $\begin{array}{l}21.89 \\
\pm 2.89\end{array}$ & $\begin{array}{l}23.21 \\
\pm 4.01\end{array}$ & $\begin{array}{l}14.89 \\
\pm 3.98\end{array}$ & $\begin{array}{l}4.35 \\
\pm 0.86\end{array}$ \\
\hline Gr. 2 & 1.45 & 20.14 & 23.74 & 16.28 & 4.06 \\
\hline
\end{tabular}

\begin{tabular}{llllll}
\hline$(\mathrm{N}=43)$ & \pm 0.16 & \pm 4.34 & \pm 2.65 & \pm 6.25 & \pm 0.66 \\
\hline Gr. 3 & 1.61 & 21.57 & 21.13 & 15.69 & 5.40 \\
$(\mathrm{~N}=42)$ & \pm 0.24 & \pm 3.31 & \pm 2.31 & \pm 6.30 & \pm 0.90 \\
\hline Total & 1.53 & 20.95 & 22.52 & 15.88 & 4.68 \\
$(\mathrm{~N}=94)$ & \pm 0.21 & \pm 3.82 & \pm 2.92 & \pm 6.06 & \pm 1.02 \\
\hline
\end{tabular}

Table IV. Physical fitness measurements by age (girls)

\begin{tabular}{llllll} 
& SLJ & Sit-up & $10 \times 5 \mathrm{~m}$ & Flamingo & Ball throw \\
\hline Gr. 1 & 1.32 & 18.07 & 23.96 & 17.07 & 3.87 \\
$(\mathrm{~N}=15)$ & \pm 0.19 & \pm 3.41 & \pm 1.55 & \pm 7.67 & \pm 0.99 \\
\hline Gr. 2 & 1.41 & 18.30 & 24.91 & 13.71 & 4.10 \\
$(\mathrm{~N}=89)$ & \pm 0.18 & \pm 3.59 & \pm 2.53 & \pm 7.79 & \pm 0.70 \\
\hline Gr. 3 & 1.45 & 16.85 & 21.88 & 15.50 & 4.43 \\
$(\mathrm{~N}=54)$ & \pm 0.88 & \pm 3.98 & \pm 1.94 & \pm 7.96 & \pm 0.93 \\
\hline Total & 1.42 & 17.78 & 23.78 & 14.64 & 4.10 \\
$(\mathrm{~N}=158)$ & \pm 0.19 & \pm 3.75 & \pm 2.66 & \pm 7.87 & \pm 0.83 \\
\hline
\end{tabular}

As for differences between genders, boys have proven more strength in the lower and upper limbs, as well as more developed abdominal muscles, and girls have a better balance compared to boys.

Statistical differences were obtained with Bonferoni test for multiple comparisons between groups. In the male group (Table V), significant differences $(p<0.05)$ were obtained between group 2 and 3 for standing long jump, agility test $10 \times 5 \mathrm{~m}$ and medicine ball throw. The mean difference is also significant between groups 1 and 3 .

Table V. Physical fitness measurements by age Multiple comparisons with Bonferoni (boys)

\begin{tabular}{|c|c|c|c|c|c|}
\hline & SLJ & Sit-up & $\begin{array}{l}10 \times 5 \\
\mathrm{~m}\end{array}$ & $\begin{array}{l}\text { Flami } \\
\text { ngo }\end{array}$ & $\begin{array}{l}\text { Ball } \\
\text { throw }\end{array}$ \\
\hline $\begin{array}{l}\text { Mean } \\
\text { differences } \\
(\text { Gr } 1-\text { Gr 2) }\end{array}$ & 0.044 & 1.749 & -0.53 & -1.390 & 0.289 \\
\hline $\begin{array}{l}\text { Mean } \\
\text { differences } \\
\text { (Gr 1-Gr 3) }\end{array}$ & -0.118 & 0.317 & 2.081 & -0.802 & $-1.050^{*}$ \\
\hline $\begin{array}{l}\text { Mean } \\
\text { differences } \\
(\text { Gr } 2-\text { Gr 3) }\end{array}$ & $-0.163^{*}$ & -1.432 & $2.61 \%$ & 0.589 & $-1.339^{*}$ \\
\hline
\end{tabular}

\section{Discussions}

These differences are predicted by the puberty period for both genders [9]. Previous studies reported $1.55 \mathrm{~cm}$ height and $50 \mathrm{~kg}$ weight in 12 years old; $1.53 \mathrm{~cm}$ [10] and $47.74 \mathrm{~kg}$ in 13 years old [11]; $1.57 \mathrm{~m}$ and $48.29 \mathrm{~kg}$ for 12.51 years old nonathletes female [12]. The anthropometric characteristics increased with age, as expected for all measurements.

We also observed that the BMI increased for both groups of genders. Our results concur with those reported by Castro-Pinero et al (2010), whereas Caswell et al (2016) suggested a normal weight after two years of experience in American football $[13,14]$. Waist and hip circumference showed an increasing trend with age among both girls and boys, similar with the Greek population [15]. 
This is an expected finding during puberty, as it represents a critical period for the development and distribution of body fat [16]. The effects of physical education during this phase of life are difficult to distinguish from those of normal growth and development [17]. Sauka et al. (2015) suggested that boys performed better than girls in muscular endurance, lower body muscular strength, upper body muscular strength and speed agility. Research results show that our data are consistent with the scientific literature in the field, for both girls and boys $[18,19,20]$. In a research published in Turkey, for subject aged 12, results were 23.8 times more for boys and 26.3 times more for girls in comparison to the subjects of the same age included in our study [21]. Standing long jump could be considered as a general index for muscular fitness in young subjects [13]. Previous studies reported two characteristics of strength: (1) a significant association between lower body muscular strength and upper body muscular strength [13], and (2) young adults performed best and children performed worst [22].

Sekeljig's study (2016) showed balance as the ability to maintain body equilibrium during different movements and in different positions.

Our investigation report showed that girls performed better in the Flamingo test. It depends on information, visual analyzers, and kinaesthetic analyzers as well as on the vestibular apparatus [23]. This is the reason why the best, but also the most stable results for this motor skill can be expected only after 12 years of age [24].

\section{Conclusions}

The literature indicates that physical fitness is an important health marker starting from young ages. Correct interpretation of physical fitness assessment requires comparing the score with normative values for the general population of the same age and gender.

The results of the present study showed that physical fitness performance was better in male students except from balance, where female students performed better.

Future research needs to examine methods for increasing physical fitness level among pupils and young student and identify cut-points related to health.

\section{References}

1. Canhadas I.L., Lopez R., Silva P., Rodrigures C., Leslie C., Portes A. (2010). Anthropometric and physical fitness characteristics of young male soccer player, Rev. Bras. Cineantropom. Desempenho Hum., 12(4), pp. 239-245.

2. Cordova A., Villa G., Sureda A., Rodriques-Marrovo J.A., Sanchez-Collado M.P. (2012). Physical Activity and
Cardiovascular Risk Factors in Spanish Children Aged 11-13 Years, Rev. Esp. Cardiol., 65(7), pp. 620-6.

3. Cordun M. (2009). Kinantropometrie, Editura CD Press, București (in Romanian).

4. Fuster V., Topol E.J., Nabel E.G. (2005). Atherothrombosis and coronary artery disease, New York: Lippincott Williams \& Wilkins.

5. Gallahue D.L., Cleland-Donnelly F. (2003). Developmental physical education for all children, Human Kinetics, pp. 9-91.

6. García-Ortiz L., Grandes G., Sánchez-Pérez A., Montoya I., Iglesias-Valiente J.A., Recio-Rodríguez J.I., et al. (2010). Efecto en el riesgo cardiovascular de una intervención para la promoción del ejercicio físico ensujetos sedentarios por el médico de familia, Rev. Esp. Cardiol., 63, pp. 1244-52.

7. International Society for the Advancement of Kinanthropometry (2001). International Standards for anthropometric assessment, Potchefstroom, South Africa.

8. Mackenzie B. (2004). 101 Performance Evaluation, Tests, Electric World Plc., London.

9. Moraru C., Radu L.E. (2014). Aspects Regarding the Level of Coordinative Abilities in both Athletes and Non-Atheletes, (ICSPEK 2013), Procedia Social and Behavioral Sciences, vol. 117, pp. 162-166.

10. Pearson D.T., Naughton G.A., Torode M. (2006). Predictability of physiological testing and the role of maturation in talent identification for adolescent team sports, J. Sci. Med. Sports, 9, pp. 277-87.

11. Popovici I.M., Radu L.E (2014). Anthropometric and Physical Fitness Analyses between Female Handball Players and Sedentary Girls, Gymnasium, Scientific Journal on Education, Sports and Health, XV(1), pp. 95-108.

12. Radu L.E., Vanvu G. (2012). 11-13 years children's motor skills - athletes and non-athletes. Comparative study, Gymnasiun, Scientific Journal of Education, Sport and Health. Supplement vol. XIII, pp. 271-274.

13. Castro-Pinero J., Ortega F.B., Artero E.G., Girela-Rejon M.J., Mora J., et al. (2010). Assessing muscular strength in youth: usefulness of standing long jump as a general index of muscular fitness, Journal of Strength and Conditioning Research, 24(7), pp. 1810-1817.

14. Caswell S.V., Ausborn A., Diao G., et al. (2016). Anthropometrics, Physical Performance, and Injury Characteristics of Youth American Football, Ortopaedic Journal of Sports Medicine, 4 (8), 2325967116662251.

15. Bacapoulou F., Efthymiou V., Landis G., Rentoumis A., Chrousos G. (2015). Waist circumference, waist-to-hip ratio and waist-to-height ratio reference percentiles for abdominal obesity among Greek adolescents, BMC Pediatrics, 15, p. 50,

16. Maffeis C., Pietrobelli A., Grezzani A., Provera S., Tato L. (2001). Waist circumference and cardiovascular risk factors in pre-pubertal children, Obes Res., 9, pp. 179-87.

17. Rogol A.D., Clark P.A., Roemmich J.N. (2000). Growth and pubertal development in children and adolescents: effects of diet and physical activity, Am. J. Clin. Nutr. 72(Suppl.), pp. 521S-8S.

18. Sauka M., Priedite I.S., Artiuhova L., et al. (2011). Physical fitness in northern European youth: Reference values from the Latvian Physical Health in Youth Study, Scandinavian Journal of Public Health, 37(1), pp. 35-43.

19. Simsek E., Aktug Z.B., Celenik C., et al. (2014). The Evaluation of Physical Characteristics of Football Players at the Age of 915 in Accordance With Age Variables, International Journal of Science Culture and Sport, 1, pp. 460-468.

20. Vestraete S.J., Cardon G.M., De Clerq D.L., De Bourdeaudhuij I.M. (2007). A comprehensive physical activity promotion programme at elementary school: the effects on physical activity, physical fitness and psychosocial correlates of physical activity. Public Health Nutrition, 10(5), pp. 477-484.

21. Yuksel O., Tamer K., Caliscan G. (2014). Evaluate the physical fitness levels of Turkish primary school male and female 
Timișoara Physical Education and Rehabilitation Journal

children between 7-14 ages, Ovidius University Annals, Series Physical Education and Sports, 14(2), pp. 585-593.

22. Skowronski W., Horvat M., Nocera J., et al. (2009). Eurofit special: European Fitness Battery Score Variation Among Individuals With Intellectual Disabilities, Adapted Physical Activity Quarterly, 26, pp. 54-67.

23. Sekeljig G., Stamatovic M., Markovic J. (2016). Virtual space of the basic motoric structures, Facta Universitatis, Series Physical Education and Sport, 14(1), pp. 99-108.
24. Gajic M. (1985). Basics of human motorics, Novi Sad: Faculty of Physical Culture. 